\title{
Isosporoid Coccidia (Apicomplexa: Eimeriidae) parasites of Tanagers (Passeriformes: Thraupidae) from the Marambaia Island, Brazil ${ }^{1}$
}

\author{
Bruno P. Berto ${ }^{2 *}$, Hermes R. Luz ${ }^{3}$, Walter Flausino², Walter L. Teixeira-Filho', \\ Ildemar Ferreira ${ }^{4}$ and Carlos Wilson G. Lopes ${ }^{2}$
}

\begin{abstract}
Berto B.P., Luz H.R., Flausino W., Teixeira-Filho W.L., Ferreira I. \& Lopes C.W.G. 2011. Isosporoid Coccidia (Apicomplexa: Eimeriidae) parasites of Tanagers (Passeriformes: Thraupidae) from the Marambaia Island, Brazil. Pesquisa Veterinária Brasileira 31(9):798-805. Departamento de Parasitologia Animal, Instituto de Veterinária, Universidade Federal Rural do Rio de Janeiro, Seropédica, RJ 23890-000, Brazil. E-mail: bertobp@ufrrj.br

In recent years some coccidian parasites of birds were recorded in Marambaia Island, which is a protected environment with a great biodiversity of birds, mainly tanagers. In this current study Isospora tiesangui, I. sepetibensis, I. ramphoceli, I. navarroi, I. cadimi and I. marambaiensis were identified according to their respective thraupid hosts of the Marambaia Island. These species were characterized with histograms, linear regression and analysis of variance (ANOVA). The main feature of identification was the morphology of the sporocyst, mainly Stieda and substieda bodies, since the morphometry did not provide sufficient differentiation. Besides, Dacnis cayana and Thraupis palmarum were reported as new hosts to I. sepetibensis and I. navarroi respectively.
\end{abstract}

INDEX TERMS: Coccidiosis, diagnostic, Thraupids, Passerine birds, Marambaia Island.

RESUMO.- [Coccídios isosporóides (Apicomplexa: Eimeriidae) parasitos de traupídeos (Passeriformes: Thraupidae) da ilha de Marambaia, Brasil] Nos últimos anos, alguns coccídios de aves foram registrados na Ilha da Marambaia, que é um ambiente protegido com uma grande biodiversidade de aves, principalmente traupídeos. No presente estudo Isospora tiesangui, I. sepetibensis, I. ramphoceli, I. navarroi, I. cadimi e I. marambaiensis foram identificadas de acordo com suas respectivos hospedeiros da Ilha da Marambaia, RJ. Essas espécies foram caracterizadas com histogramas, regressão linear e análise de variância (ANOVA). A principal característica de identificação foi a morfologia do esporocisto, principalmente os cor-

\footnotetext{
${ }^{1}$ Received on March 25, 2011.

Accepted for publication on April 15, 2011.

Supported by CNPq and Faperj.

${ }^{2}$ Departamento de Parasitologia Animal, Instituto de Veterinária, Universidade Federal Rural do Rio de Janeiro (UFRRJ), BR $465 \mathrm{Km}$ 7, Seropédica, RJ 23890-000, Brazil. *Corresponding author: bertobp@ufrri.br; other emails: flausino@ufrrj.br, leira@ufrrj.br, lopescwg@ufrrj.br - CNPq fellowship.

${ }^{3}$ Curso de Pós-Graduação em Ciências Veterinárias, UFRRJ, Seropédica, RJ. E-mail: hermes@ufrrj.br

${ }^{4}$ Zoologia, Departamento de Biologia Animal, Instituto de Biologia, UFRRJ, BR 465 km 7, Seropédica, RJ 23890-000, Brasil. E-mail: ferreira@ufrrj.br
}

pos de stieda e substieda, uma vez que a morfometria não forneceu diferenciação suficiente. Além disso, Dacnis cayana e Thraupis palmarum foram registrados como novos hospedeiros para I. sepetibensis e I. navarroi respectivamente.

TERMOS DE INDEXAÇÃO: Coccidiose, diagnóstico, Traupídeos, Passeriformes, Ilha de Marambaia.

\section{INTRODUCTION}

The Marambaia Island is an environmentally protected area which holds a great biodiversity of birds that represent a sampling of New World passerine species observed in the biomes of Atlantic Forest, Restinga and Mangrove. The island is situated on the coast of Costa Verde, near to Sepetiba Bay, south of the State of the Rio de Janeiro, in Brazil (Araújo 2008).

In the island can be observed New World passerine birds of several families, principally, Thraupidae. Among the thraupids frequently observed, detached by the intense and varied colorful: the tanagers of the genus Tangara (Brisson, 1760); the honeycreepers of the genus Cyanerpes (Oberholser, 1899); the dacnis of the genus Dacnis (Cuvier, 1816); the manakins of the genus Chiroxiphia (Cabanis, 1847); and the Brazilian tanager Ramphocelus bresilius dorsalis (Sclater, 1855) (Sick 1997, CBRO 2010, IUCN 2011). 
In the last three years, some coccidian parasites were reported from birds of this island. Among these coccidia, some parasitized three distinct host species. The pathogenic relevance of these parasites to theirs naturally infected hosts was not recognized yet, although the captured passerine birds were apparently healthly (Berto et al. 2008a,b, 2009a,b,c,d, 2010a,b, 2011).

From thraupids of the Marambaia Island, six Isospora (Schneider, 1881) species were recorded: (1) Isospora tiesangui (Berto et al, 2008); (2) Isospora marambaiensis (Berto et al., 2008); (3) Isospora sepetibensis (Berto et al., 2008); (4) Isospora cadimi (Berto et al., 2009); (5) Isospora navarroi (Berto et al, 2009) and (6) Isospora ramphoceli (Berto et al., 2010). All these species were described from the Brazilian tanager R.b. dorsalis (Berto et al. 2008a, 2009a, 2010b); however, I. tiesangui was recently reported from the palm tanager Thraupis palmarum (Wied, 1823), and blue dacnis Dacnis cayana (Linnaeus, 1766) (Berto et al. 2010a).

Thus, this study aims to characterize morphologically and morphometrically the Isospora species sporulated oocysts, parasites of tanagers from the Marambaia Island, besides to report new hosts to I. sepetibensis and I. navarroi.

\section{MATERIALS AND METHODS}

\section{Stool samples from tanagers of the Marambaia Island}

The birds were captured using nets on Marambaia Island $\left(23^{\circ} 04^{\prime} \mathrm{S}, 43^{\circ} 53^{\prime} \mathrm{W}\right)$, kept in individual cage, and faeces were collected immediately after defecation. Following its identification by one of us, Dr Ildemar Ferreira (Ornithologist), the bird was released and the samples were placed in plastic vials containing $2.5 \%$ potassium dichromate solution $\left(\mathrm{K}_{2} \mathrm{Cr}_{2} \mathrm{O}_{7}\right)$ 1:6 (v/v). A total of 62 faecal samples were collected from tanagers.

\section{Samples processing}

Samples were carried to the Laboratório de Coccídios e Coccidioses (Projeto Sanidade Animal (Embrapa/UFRRJ), Departamento de Parasitologia Animal, Instituto de Veterinária, Universidade Federal Rural do Rio de Janeiro. Samples were placed in a thin layer (c. $5 \mathrm{~mm}$ ) of $\mathrm{K}_{2} \mathrm{Cr}_{2} \mathrm{O}_{7} 2.5 \%$ solution in Petri plates and incubated at 23 to $28^{\circ} \mathrm{C}$ for 10 days or until $70 \%$ of the oocysts were sporulated. Oocysts were recovered by flotation in Sheather's sugar solution (S.G. 1.20) and examined microscopically by using the technique described by Duszynski \& Wilber (1997).

\section{Observing, measuring and drawing oocysts}

Morphological observations and measurements, given in $\mu \mathrm{m}$, were made using a Carl Zeiss binocular microscope (Germany) with an apochromatic oil immersion objective lens and an ocular micrometer (K-15X PZO, Poland). Line drawings were prepared using a Wild/Leitz M-20 (Germany) binocular microscope with a drawing tube. Size ranges are shown in parenthesis followed by average and shape index (L/W ratio). Abbreviations: total number of measurements [T], micropyle [M], oocyst residuum [OR], oocyst wall [OW], polar granule [PG], Stieda body [SB], substieda body [SSB], parastieda body [PSB], sporocyst residuum [SR], sporozoite [SZ], refractile body [SRB], nucleus [N], length [L] and width [W].

\section{Statistical evaluation}

Three statistical methods were performed: (1) Histograms were prepared to plot the values of length, width and shape-index of the sporulated oocysts, with their frequencies, according to Sampaio (2002) and Berto et al. (2008c,d,e); (2) Analysis of variance
(ANOVA) was used to compare measurements of length, width and shape-index of the sporulated oocysts and sporocysts in two situations: first, comparing Isospora spp. recovered from the familyhost and, second, comparing Isospora sp. recovered from different host species. For this, the software Microsoft $®$ Excel 2007 was used to calculate the mean, variance, degree of freedom and $p$ value (Gomez et al. 1982, Sampaio 2002, Berto et al. 2008c,d,e); (3) linear regression aimed to assess measures of width on length of Isospora sp. oocysts. When different host species shed Isospora sp. oocysts, regressions were performed for each host individually, but the graphics were superimposed for better visualization. The method is in agreement with Norton \& Joyner (1981), Sampaio (2002) and Berto et al. (2008c,d,e). Graphics with the waste and coefficients of regression lines were obtained through the software Microsoft Excel 2007®.

\section{RESULTS}

Fecal samples of 62 tanagers were obtained. When they were trapped at the Marambaia Island they were apparently healthy, including those infected by coccidia (Table 1). Six Isospora species were recovered from tanagers $R$. b. dorsalis, D. cayana and T. palmarum. These were identified as: I. tiesangui, I. sepetibensis, I. ramphoceli, I. navarroi, I. cadimi, and I. marambaiensis.

Isospora tiesangui and I. sepetibensis were the most frequent. From $R$. $b$. dorsalis were recovered all these Isospora species, while that I. tiesangui and I. sepetibensis were recovered from D. cayana, and from T. palmarum were diagnosed I. tiesangui and I. navarroi. The distribution of these Isospora species per fecal sample of tanagers was observed on Table 2.

Few of these Isospora species could be distinguished and identified by morphometry (Table 3). In this sense, the detailed observations of the morphology of the sporulated oocysts and sporocysts were necessary for identification (Fig.1,2).

\section{Isospora tiesangui}

This species was isolated from the Brazilian tanager R.b. dorsalis, blue dacnis D. cayana and palm tanager T. palmarum.

The identified sporulated oocysts (Fig.1a, 2a) were spherical to sub-spherical. OW bi-layered and smooth, 1.3

Table 1. Totality of passerine thraupids captured on the Marambaia island according to species and positiveness

\begin{tabular}{|c|c|c|c|c|}
\hline \multicolumn{2}{|c|}{ Passerine species } & \multicolumn{3}{|c|}{ Samples } \\
\hline Scientific name & Common name & Positive & Negative & Total \\
\hline $\begin{array}{r}\text { Ramphocelus bresilius } \\
\text { dorsalis Sclater, } 1855\end{array}$ & Brazilian tanager & 9 & 20 & 29 \\
\hline $\begin{array}{l}\text { Tachyphonus coronatus } \\
\text { Vieillot, } 1822\end{array}$ & $\begin{array}{l}\text { Ruby-crowned } \\
\text { tanager }\end{array}$ & 0 & 6 & 6 \\
\hline $\begin{array}{l}\text { Trichothraupis melanops } \\
\text { Vieillot, } 1818\end{array}$ & $\begin{array}{l}\text { Black-goggled } \\
\text { tanager }\end{array}$ & 0 & 1 & 1 \\
\hline $\begin{array}{l}\text { Dacnis cayana } \\
\text { Linnaeus, } 1766\end{array}$ & Blue dacnis & 4 & 15 & 19 \\
\hline $\begin{array}{l}\text { Tangara cayana } \\
\text { Linnaeus, } 1766\end{array}$ & $\begin{array}{l}\text { Burnished-buff } \\
\text { tanager }\end{array}$ & 0 & 1 & 1 \\
\hline $\begin{array}{l}\text { Thraupis palmarum } \\
\text { Wied, } 1823\end{array}$ & Palm tanager & 2 & 2 & 4 \\
\hline T. sayaca Linnaeus, 1766 & Sayaca tanager & 0 & 2 & 2 \\
\hline Total & & 15 & 47 & 62 \\
\hline
\end{tabular}


Table 2. Distribution and totality of oocysts per faecal sample for Isospora spp. recovered from tanagers of the Marambaia Island, Brazil

\begin{tabular}{|c|c|c|c|c|c|c|c|c|}
\hline \multirow{2}{*}{\multicolumn{2}{|c|}{ Samples ${ }^{a}$}} & \multicolumn{6}{|c|}{ Identified oocysts } & \multirow{2}{*}{$\begin{array}{l}\text { Number } \\
\text { of species }\end{array}$} \\
\hline & & $\begin{array}{l}\text { Isospora } \\
\text { tiesangui }\end{array}$ & $\begin{array}{l}\text { I. maram- } \\
\text { baiensis }\end{array}$ & $\begin{array}{l}\text { I. sepeti- } \\
\text { bensis }\end{array}$ & I. cadimi & I. navarroi & $\begin{array}{l}\text { I. ram- } \\
\text { phoceli }\end{array}$ & \\
\hline \multirow{9}{*}{ 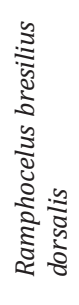 } & I & 15 & 11 & 9 & 0 & 0 & 0 & 3 \\
\hline & II & 1 & 0 & 2 & 5 & 8 & 0 & 4 \\
\hline & III & 0 & 0 & 4 & 4 & 6 & 0 & 3 \\
\hline & IV & 0 & 0 & 3 & 1 & 5 & 0 & 3 \\
\hline & V & 0 & 0 & 0 & 3 & 1 & 0 & 2 \\
\hline & VI & 0 & 0 & 0 & 1 & 0 & 0 & 1 \\
\hline & VII & 4 & 0 & 18 & 27 & 3 & 13 & 5 \\
\hline & VIII & 0 & 0 & 13 & 20 & 16 & 26 & 4 \\
\hline & IX & 8 & 0 & 1 & 0 & 0 & 2 & 3 \\
\hline \multirow{6}{*}{ 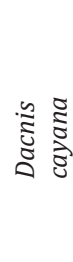 } & $\begin{array}{l}\text { Total of } \\
\text { ositives }\end{array}$ & 4 & 1 & 7 & 7 & 6 & 3 & \\
\hline & I & 0 & 0 & 2 & 0 & 0 & 0 & 1 \\
\hline & II & 11 & 0 & 0 & 0 & 0 & 0 & 1 \\
\hline & III & 1 & 0 & 13 & 0 & 0 & 0 & 2 \\
\hline & IV & 3 & 0 & 0 & 0 & 0 & 0 & 1 \\
\hline & $\begin{array}{l}\text { Total of } \\
\text { ositives }\end{array}$ & 3 & 0 & 2 & 0 & 0 & 0 & \\
\hline \multirow{2}{*}{ 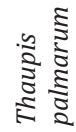 } & I & 5 & 0 & 0 & 0 & 0 & 0 & 1 \\
\hline & II & 2 & 0 & 0 & 0 & 11 & 0 & 2 \\
\hline \multirow{3}{*}{\multicolumn{2}{|c|}{$\begin{array}{l}\text { Total of positives } \\
\text { Total of oocysts } \\
\text { : } \\
\text { Total of positives }\end{array}$}} & 2 & 0 & 0 & 0 & 1 & 0 & \\
\hline & & 50 & 11 & 65 & 61 & 50 & 41 & \\
\hline & & 9 & 1 & 9 & 7 & 7 & 3 & \\
\hline
\end{tabular}

${ }^{a}$ Fecal samples collected per host, indicated by Roman numerals, b total of Isospora spp. recovered in the same sample, ${ }^{c}$ total of positive samples for each Isospora sp. per host, ${ }^{\mathrm{d}}$ total of oocysts observed, identified and measured, ${ }^{\mathrm{e}}$ total of positive samples for each Isospora sp.

$\mu \mathrm{m} . \mathrm{M}, \mathrm{OR}$ and PG absent. Sporocysts elongate ovoidal. SB flattened, 0.5 high $\times 3.0$ wide. SSB rounded, prominent, 2.5 high $\times 4.0$ wide. PSB absent. SR composed of granules of different sizes. SZ vermiform with single posterior SRB and centrally located N. The morphometry of the sporulated oocysts of I. tiesangui, in totality and per host, can be vizualized in Tables 3 and 4 respectively.

The histograms and linear regressions of $I$. tiesangui, in totality and per host, can be vizualized in Figures 3a-c, $4 \mathrm{a}$ and 5 a respectively.

\section{Isospora sepetibensis}

This species was identified from the Brazilian tanager R. $b$. dorsalis and, in the current study, a new host for this species was identified, once that feature-similar oocysts were recovered from the blue dacnis D. cayana.

The identified oocysts (Fig.1b, 2b) were sub-spherical to ovoidal. OW bi-layered and smooth, $1.3 \mu \mathrm{m}$. M and OR absent, but one or two PG present. Sporocysts ellipsoidal. SB knob- like or bubble-shaped, 1.5 high $\times 2.0$ wide. SSB prominent, 2.0 high $\times 4.0$ wide. PSB absent. SR composed of scattered granules or forming a mass. SZ vermiform with single posterior SRB and centrally located N. The morphometry of the oocysts of I. sepetibensis, in totality and per host, can be vizualized in Tables 3 and 5 respectively.

The histograms and linear regressions of $I$. sepetibensis, in totality and per host, can be vizualized in Figures $3 \mathrm{~d}-\mathrm{f}, 4 \mathrm{~b}$ and $5 \mathrm{~b}$ respectively.

\section{Isospora ramphoceli}

This species was identified from the Brazilian tanager R. $b$. dorsalis.

The identified oocysts (Fig.1c, 2c) were spherical to subspherical. OW bi-layered and smooth, $1.2 \mu \mathrm{m}$. M, OR and PG absent. Sporocysts ellipsoidal or broadly ovoidal. SB knoblike and prominent, 1.0 high $\times 2.0$ wide. SSB large and homogenous, 2.5 high $\times 4.0$ wide. PSB absent. SR composed of granules of different sizes. SZ vermiform with single pos-

Table 3. Morphometry of Isospora spp. oocysts recovered from tanagers of the Marambaia Island, Brazil

\begin{tabular}{|c|c|c|c|c|c|c|}
\hline \multirow[t]{2}{*}{ Species } & \multicolumn{3}{|c|}{ Oocyst } & \multicolumn{3}{|c|}{ Sporocyst } \\
\hline & Length $(\mu \mathrm{m})$ & Width $(\mu \mathrm{m})$ & Shape index & Length $(\mu \mathrm{m})$ & Width $(\mu \mathrm{m})$ & Shape index \\
\hline Isospora tiesangui & $23.6(21-26)^{\mathrm{a}}$ & $22.8(20-26)^{\mathrm{a}}$ & $1.04(1.0-1.2)^{\mathrm{a}}$ & $17.2(15-20)^{\mathrm{a}}$ & $11.3(10-14)^{\mathrm{a}}$ & $1.52(1.3-1.7)^{\mathrm{a}}$ \\
\hline I. sepetibensis & $25.2(21-29)^{b}$ & $22.4(18-26)^{\mathrm{a}}$ & $1.12(1.0-1.3)^{b}$ & $17.3(16-20)^{\mathrm{a}}$ & $10.8(10-12)^{\mathrm{b}}$ & $1.60(1.4-1.8)^{\mathrm{b}}$ \\
\hline I. ramphoceli & $23.7(22-26)^{a}$ & $22.8(21-24)^{a}$ & $1.04(1.0-1.1)^{\mathrm{a}}$ & $16.0(14-18)^{b}$ & $11.4(10-13)^{a}$ & $1.41(1.3-1.6)^{\mathrm{c}}$ \\
\hline I. navarroi & $21.7(19-25)^{\mathrm{c}}$ & $20.9(18-24)^{b}$ & $1.04(1.0-1.1)^{\mathrm{a}}$ & $15.6(14-19)^{b}$ & $10.1(9-12)^{\mathrm{c}}$ & $1.55(1.4-1.7)^{\mathrm{a}}$ \\
\hline I. marambaiensis & $29.6(27-31)^{d}$ & $28.2(26-29)^{c}$ & $1.05(1.0-1.1)^{\mathrm{a}}$ & $22.7(21-25)^{c}$ & $13.0(12-14)^{\mathrm{d}}$ & $1.74(1.5-1.9)^{\mathrm{d}}$ \\
\hline I. cadimi & $23.9(21-26)^{\mathrm{a}}$ & $22.7(19-26)^{\mathrm{a}}$ & $1.05(1.0-1.1)^{\mathrm{a}}$ & $15.8(14-18)^{b}$ & $11.1(10-13)^{\mathrm{a}}$ & $1.43(1.3-1.6)^{c}$ \\
\hline
\end{tabular}

a Different letters in each column denote statistically significant differences $(\mathrm{P}<0.01)$ by ANOVA. 

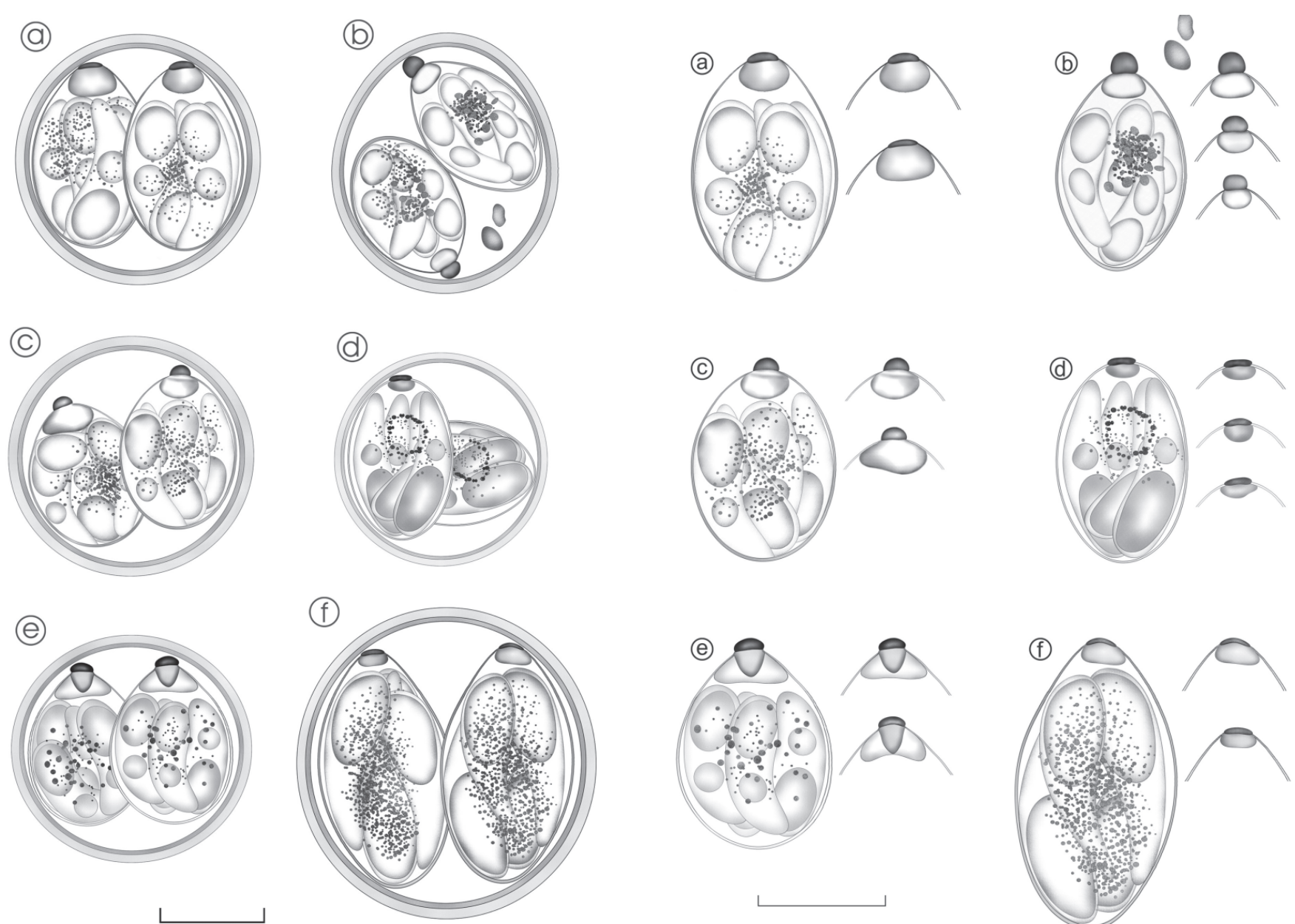

Fig.1. Line drawings of the oocysts of Isospora spp. recovered from tanagers of the Marambaia Island, Brazil: Isospora tiesangui (a); I. sepetibensis (b); I. ramphoceli (c); I. navarroi (d); I. cadimi (e); and I. marambaiensis (f). Scale-bar $=10 \mu \mathrm{m}$

terior SRB and centrally located N. The morphometry of the oocysts of I. ramphoceli can be vizualized in Table 3.

The histograms and linear regressions of I. ramphoceli can be vizualized in Figures 3g-i and 4c respectively.

\section{Isospora navarroi}

This species was identified from the Brazilian tanager R.b. dorsalis and, in the current study, a new host for this species was identified, once that feature-similar oocysts were recovered from the palm tanager T. palmarum.

The identified oocysts (Fig.1d, 2d) were spherical to subspherical. OW bi-layered and smooth, 1.1 $\mathrm{m}$. M, OR and PG absent. Sporocysts ellipsoidal. SB flattened, $0.5 \mathrm{high} \times 1.5$ wide. SSB small and delicate, 1.0 high $\times 2.5$ wide. PSB absent. SR com-
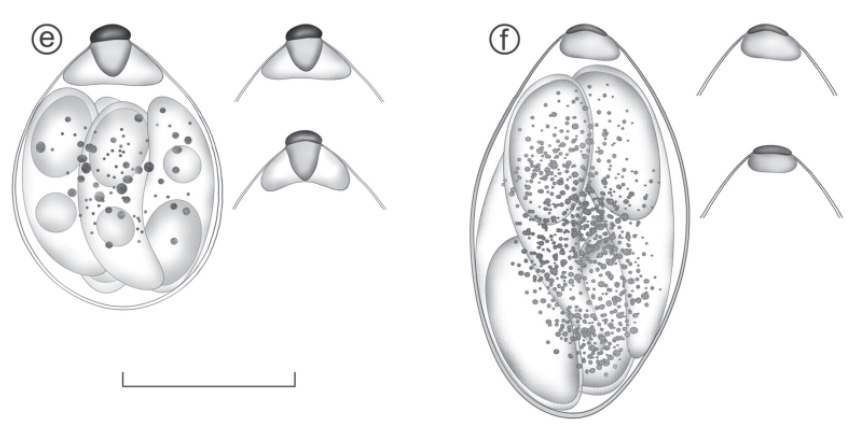

Fig.2. Line drawings of the sporocysts of Isospora spp. recovered from tanagers of the Marambaia Island, Brazil, with its respective variations of Stieda and substieda bodies detached: Isospora tiesangui (a); I. sepetibensis (b); I. ramphoceli (c); I. navarroi (d); I. cadimi (e); and I. marambaiensis (f). Scale-bar $=10 \mu \mathrm{m}$.

posed of scattered granules, which sometimes, turns into a ring form. SZ vermiform, with a robust and elongate posterior SRB. The morphometry of the oocysts of I. navarroi, in totality and per host, can be vizualized in Tables 3 and 6 respectively.

The histograms and linear regressions of I. navarroi, in totality and per host, can be vizualized in Figures 3j-m, 4d and $5 \mathrm{c}$ respectively.

\section{Isospora cadimi}

This species was identified from the Brazilian tanager R.b. dorsalis.

The identified oocysts (Fig.1e, 2e) were spherical to subspherical. OW bi-layered and smooth, 1.1 $\mathrm{m}$. M, OR and PG

Table 4. Morphometry of Isospora tiesangui oocysts recovered from three different host species of the Marambaia Island, Brazil

\begin{tabular}{|c|c|c|c|c|c|c|}
\hline \multirow[t]{2}{*}{ Host } & \multicolumn{3}{|c|}{ Oocyst } & \multicolumn{3}{|c|}{ Sporocyst } \\
\hline & Length $(\mu \mathrm{m})$ & Width $(\mu \mathrm{m})$ & Shape index & Length $(\mu \mathrm{m})$ & Width $(\mu \mathrm{m})$ & Shape index \\
\hline Ramphocelus bresilius dorsalis & $23.9(22-26)^{a}$ & $23.1(20-26)^{\mathrm{a}}$ & $1.04(1.0-1.2)^{\mathrm{a}}$ & $17.4(16-20)^{\mathrm{a}}$ & $11.4(10-13)^{\mathrm{a}}$ & $1.53(1.3-1.7)^{\mathrm{a}}$ \\
\hline Dacnis cayana & $23.1(21-26)^{\mathrm{a}}$ & $22.3(21-25)^{\mathrm{a}}$ & $1.03(1.0-1.1)^{\mathrm{a}}$ & $16.5(15-19)^{b}$ & $11.0(10-14)^{\mathrm{a}}$ & $1.51(1.4-1.6)^{\mathrm{a}}$ \\
\hline Thraupis palmarum & $23.7(22-26)^{\mathrm{a}}$ & $22.9(21-26)^{a}$ & $1.04(1.0-1.1)^{\mathrm{a}}$ & $17.8(17-19)^{\mathrm{a}}$ & $11.7(11-13)^{a}$ & $1.52(1.5-1.6)^{\mathrm{a}}$ \\
\hline
\end{tabular}

${ }^{a}$ Different letters in each column denote statistically significant differences $(\mathrm{P}<0.01)$ by ANOVA. 

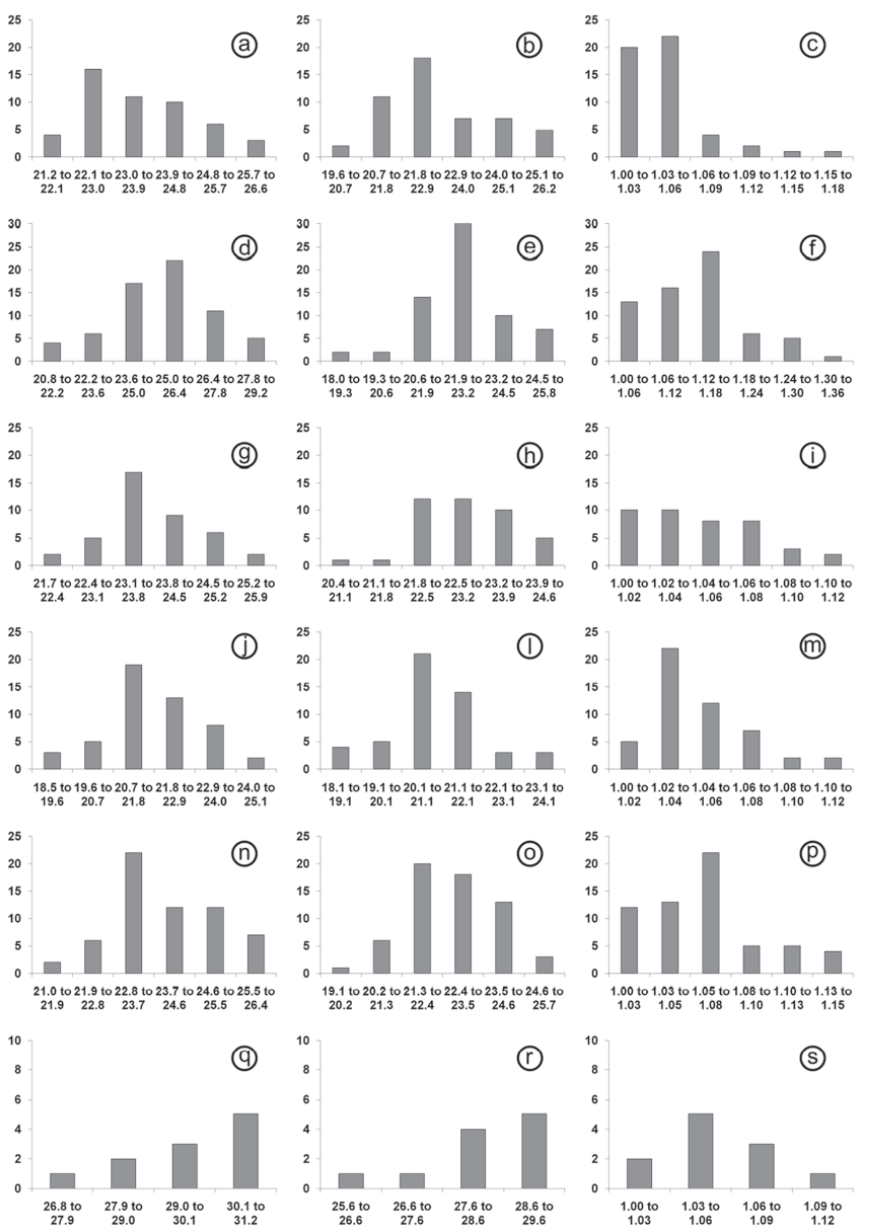

Fig.3. Histograms of length, width and shape-index of the oocysts of Isospora spp. recovered from tanagers of the Marambaia Island, Brazil: Isospora tiesangui (a-c); I. sepetibensis (d-f); I. ramphoceli (g-i); I. navarroi (j-m); I. cadimi (n-p); and I. marambaiensis (qs). Y axis: frequencies; $\mathrm{X}$ axis: classes of measures.

absent. Sporocysts broadly ovoidal, tapering toward 1 end. SB nipple-like, 1.0 high $\times 2.0$ wide. SSB prominent and compartmentalized; a central, denser portion is as wide $(\sim 2.0)$ as the SB, then tapers to cone-like shape $\sim 1.5 \mathrm{high}$; there are two wing-like structures on either side of this cone that, together, are 2.5 high $\times 4.0$ wide. PSB absent. SR composed of granules of different sizes. SZ vermiform with single posterior SRB and centrally located N. The morphometry of the oocysts of I. cadimi can be vizualized in Table 3.

The histograms and linear regressions of I. cadimi can be vizualized in Figures 3n-p and 4e respectively.

\section{Isospora marambaiensis}

This species was identified from the Brazilian tanager R.b. dorsalis. The identified sporulated oocysts (Fig.1f, 2f) were spherical to sub-spherical. OW bi-layered and smooth, $1.5 \mu \mathrm{m}$. M, OR and PG absent. Sporocysts ellipsoidal. SB flattened, 0.5 high $\times 2.0$ wide. SSB small, 1.5 high $\times 3.0$ wide. PSB absent. SR composed of granules of different sizes. SZ with a robust and elongate posterior SRB. The morphometry of the oocysts of I. marambaiensis can be vizualized in Table 3.

The histograms and linear regressions of I. marambaiensis can be vizualized in Figures 3q-s and 4f respectively.

\section{DISCUSSION}

In the histograms of length and width were observed that the frequencies in the classes rise and fall gradually; in other words, the sporulated oocyst measurements were in small quantities in the limits of values and in greater quantities in median values, characterizing regular distribution on the graphs of all species (Fig.3). Histograms of shape-index reveal to I. tiesangui, I. ramphoceli, I. navarroi and I. cadimi a higher frequency in the first classes of lower values and diminish considerably in the classes of higher values. This result supported the trend of the oocysts of these species have a spherical to sub-spherical shape. In other hand, the higher frequency in the class of values from 1.1 to 1.2 strengthens the ovoidal shape of I. sepetibensis oocysts.

Similar results were observed by Berto et al. (2008c,g) for sporulated oocysts of Isospora hemidactyli (Carini, 1936) recovered from the house gecko Hemidactylus mabouia (Moreau de Jonnès, 1818) and Eimeria bateri (Bhatia et al., 1965) from the japanese quail Coturnix japonica (Temminck et Schlegel, 1849).

The linear regression confirmed the results observed in the histograms. The $R^{2}$ value was close or above 0.5 for $I$. tiesangui, I. ramphoceli, I. navarroi and I. cadimi; therefore, the points remained near the regression line on the graph (Fig.4a, c-e). These results reveal the proportionality of values of length and width and to establish a uniform standard for the sporulated oocysts of these species. Similar results were observed in Eimeria spp. (Schneider, 1875) parasites of leyer hens (Joyner, 1982), in Hammondia heydorni (Dubey, 1977) (Pereira et al. 2001), and I. hemidactyli (Berto et al. 2008c).

In other hand, the $R^{2}$ value from the linear regression of $I$. sepetibensis was less than 0.5 and the points were distributed far from the regression line on the graph (Fig.4b). In this way, it can be stated that variations of width on length occur, and; therefore, sporulated oocysts of I. sepetibensis were polymorphic. This polymorphism was mentioned previously by Gomez et al. (1982) for oocysts of Isospora lacazei (Levine, 1982) recovered from the house sparrow Passer domesticus (Linnaeus, 1758), in the Province of Cordoba, Spain; by Gardner \& Duszynki (1990) for oocysts of Eimeria opimi (Lambert et al., 1988), from tuco-tucos Ctenomys spp.

Table 5. Morphometry of Isospora sepetibensis oocysts recovered from two different host species of the Marambaia Island, Brazil

\begin{tabular}{cccccccc}
\hline \multirow{2}{*}{ Host } & \multicolumn{3}{c}{ Oocyst } & & \multicolumn{3}{c}{ Sporocyst } \\
\cline { 2 - 3 } \cline { 5 - 7 } & Length $(\mu \mathrm{m})$ & Width $(\mu \mathrm{m})$ & Shape index & & Length $(\mu \mathrm{m})$ & Width $(\mu \mathrm{m})$ & Shape index \\
\hline Ramphocelus bresilius dorsalis & $25.3(21-29)^{\mathrm{a}}$ & $22.7(18-26)^{\mathrm{a}}$ & $1.12(1.0-1.3)^{\mathrm{a}}$ & & $17.2(16-20)^{\mathrm{a}}$ & $10.8(10-12)^{\mathrm{a}}$ & $1.60(1.4-1.8)^{\mathrm{a}}$ \\
Dacnis cayana & $24.8(22-27)^{\mathrm{a}}$ & $21.7(20-23)^{\mathrm{a}}$ & $1.14(1.0-1.3)^{\mathrm{a}}$ & & $17.4(16-18)^{\mathrm{a}}$ & $10.9(10-12)^{\mathrm{a}}$ & $1.59(1.5-1.7)^{\mathrm{a}}$
\end{tabular}

a Different letters in each column denote statistically significant differences $(\mathrm{P}<0.01)$ by ANOVA. 

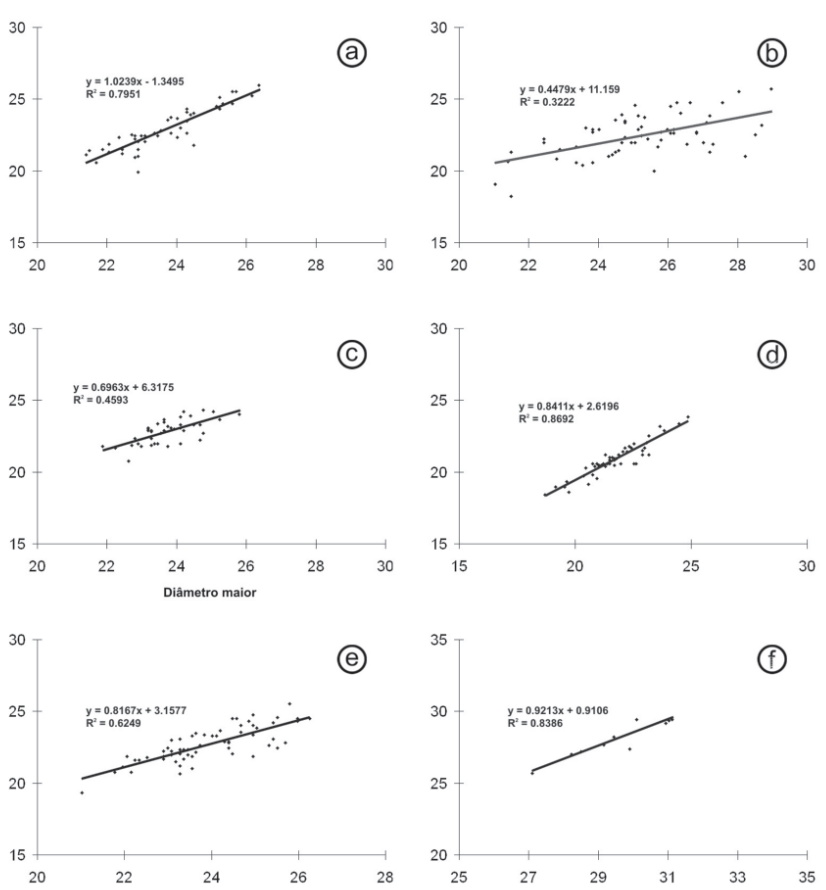

Fig.4. Linear regressions of the oocysts of Isospora spp. recovered from tanagers of the Marambaia Island, Brazil: Isospora tiesangui (a); I. sepetibensis (b); I. ramphoceli (c); I. navarroi (d); I. cadimi (e); and I. marambaiensis (f). Y axis: width; X axis: length.

(Blainville, 1826), in Bolivia; by Berto et al. (2008d) for oocysts of Tyzzeria parvula (Klimes, 1963) recovered from the Greylag goose Anser anser (Linnaeus, 1758); and by Ramirez et al. (2009b) for oocysts of Eimeria bareillyi (Gill et al., 1963) of the domestic water buffalo Bubalus bubalis (Linnaeus, 1758).

Different factors should be associated with this polymorphism as follwed: stress; nutrition; immunity of the host; the infecting dosage (Fayer 1980, Joyner 1982); the time of oocyst discharge during the patent period (Duszynski 1971, Catchpole et al. 1975, Joyner 1982); and the phenotypic plasticity, when a coccidium activates different phenotypes in response to its environment (Parker \& Duszynski 1986, Gardner \& Duszynski 1990).

Only a single sample of $R$. $b$. dorsalis was positive for $I$. marambaiensis and few oocysts of this species were found, identified and measured (Table 2). Therefore, these few data do not allow characterizing the oocysts of I. marambaiensis, although the statistical evaluations suggested uniform standard.

The comparative linear regression (Fig.5) shows the consistency in the distribution of the dimensions of the oocysts recovered from the hosts of I. tiesangui, I. sepetibensis and $I$. navarroi, since the lines were positioned close and with regression lines and $R^{2}$ values. These conclusions were also reported to the comparative regressions of $H$. heydorni from different hosts by Pereira et al. (2001); Eimeria spp. from sheep by Hassum et al. (2007); and Eimeria spp. from young and adult goats by Ramirez et al. (2009a).

The ANOVA performed to Isospora sp. recovered from the different host species resulted in equivalent means between all dimensions, with the exception of the sporocyst length of
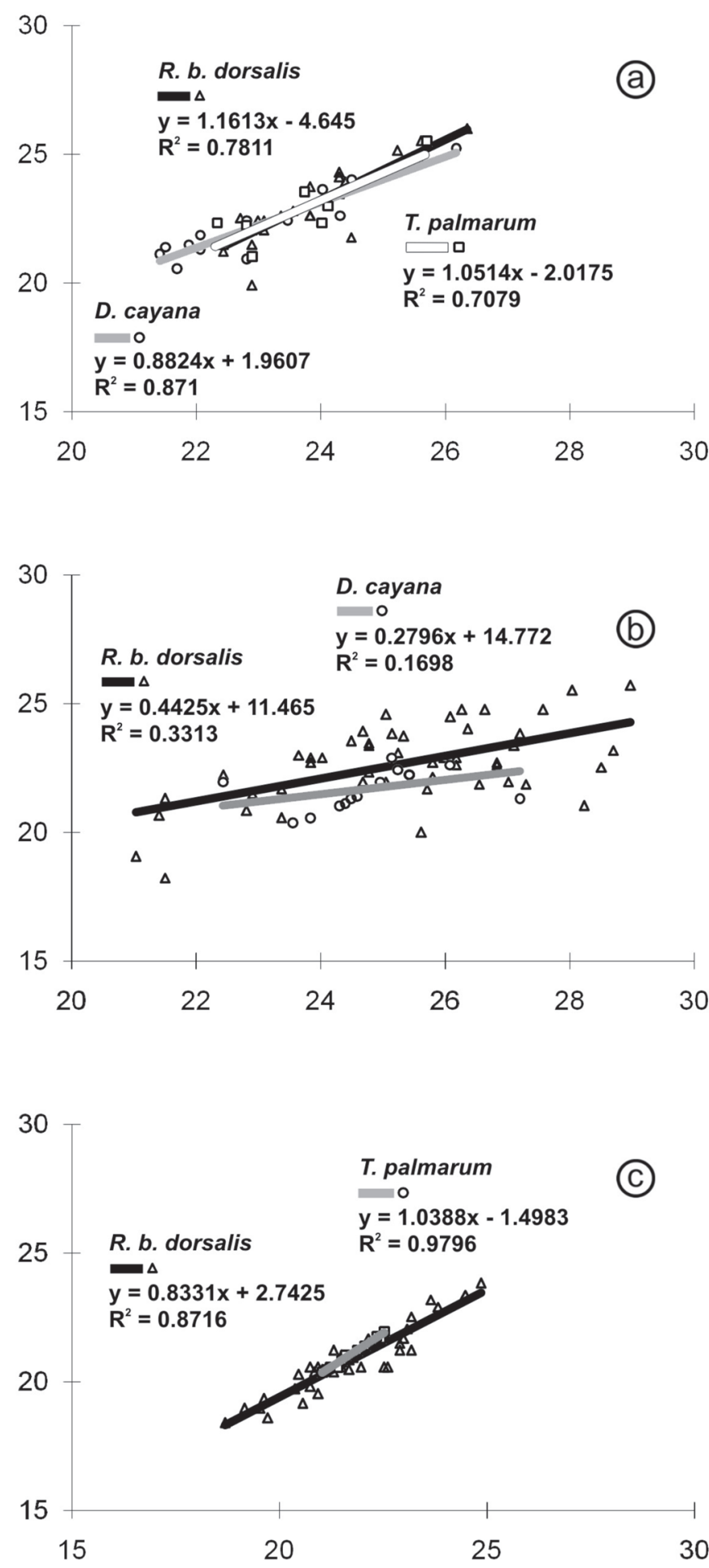

Fig.5. Comparative linear regressions of the oocysts of Isospora spp. recovered from different host species of the Marambaia Island, Brazil: Isospora tiesangui (a); I. sepetibensis (b); I. navarroi (c). $\mathrm{Y}$ axis: width; $\mathrm{X}$ axis: length.

I. tiesangui from D. cayana and R. b. dorsalis, and D. cayana and T. palmarum. This significant difference was justified due to variables that can influence the accuracy of the measurement of the sporocyst length; the position of the oocyst and sporocyst under the coverslip; and the pressure which the sporocysts are submitted within the oocyst walls.

In the Table 3 and Figure 6 were observed that few 
Table 6. Morphometry of Isospora navarroi oocysts recovered from two different host species of the Marambaia Island, Brazil

\begin{tabular}{|c|c|c|c|c|c|c|}
\hline \multirow[t]{2}{*}{ Host } & \multicolumn{3}{|c|}{ Oocyst } & \multicolumn{3}{|c|}{ Sporocyst } \\
\hline & Length $(\mu \mathrm{m})$ & Width $(\mu \mathrm{m})$ & Shape index & Length $(\mu \mathrm{m})$ & Width $(\mu \mathrm{m})$ & Shape index \\
\hline Ramphocelus bresilius & $21,7(19-25)^{a}$ & $20,8(18-24)^{a}$ & $1,04(1,0-1,1)^{\mathrm{a}}$ & $15,6(14-19)^{a}$ & $10,1(9-12)^{a}$ & $1,55(1,4-1,7)^{\mathrm{a}}$ \\
\hline Thraupis palmarum & $21,7(21-23)^{a}$ & $21,1(20-22)^{a}$ & $1,03(1,0-1,0)^{\mathrm{a}}$ & $15,7(15-17)^{a}$ & $10,1(10-10)^{a}$ & $1,56(1,5-1,6)^{a}$ \\
\hline
\end{tabular}

${ }^{a}$ Different letters in each column denote statistically significant differences $(\mathrm{P}<0.01)$ by ANOVA.

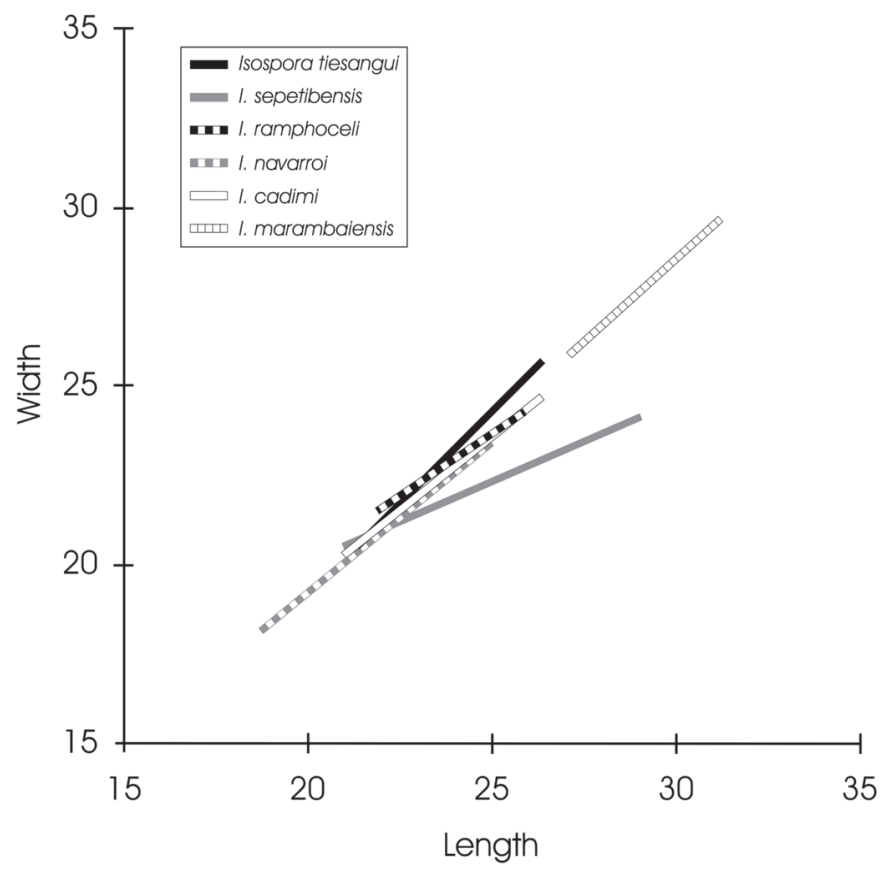

Fig.6. Comparative linear regressions of the oocysts of Isospora spp. recovered from from tanagers of the Marambaia Island, Brazil.

sporulated oocysts recovered from tanagers of the Marambaia Island were distinguished by using the morphometry of the sporulated oocysts. Isospora tiesangui, I. ramphoceli and I. cadimi had equivalent means between all dimensions of the oocysts.

Isospora marambaiensis oocysts had larger dimensions than the other species and, therefore, its regression line had an isolated location in Figure 6. This species was easily differentiated from oocysts of other species even when observed at $400 \mathrm{x}$ magnification.

Isospora sepetibensis, despite having ovoidal oocysts, its presents equivalent means of width similar to I. tiesangui, $I$. ramphoceli and I. cadimi (Table 3). Therefore, depending on the position of the oocyst of I. sepetibensis under cover slip, it may have dimensions similar to these species.

Isospora navarroi was the species with smaller oocysts; however, when observed at 400X magnification, the identification is difficult. In the comparative linear regression (Fig.6) and also in Table 3 was observed that the upper limits of the values of oocyst dimensions coincide with the values of $I$. sepetibensis, I. tiesangui, I. ramphoceli and I. cadimi.

These results support that, the differentiation of these species by morphometry was not reliable. Therefore, a morphological observation of the sporulated oocysts, sporocysts and structures as SB and SSB in 1000X magnification, were important to identify these species (Fig.1,2).
Only the oocysts of I. sepetibensis present PG among these species; therefore, it was easily to identify this structure. In $I$. cadimi was observed compartments in SSB that distinguishes it from others species.

Isospora tiesangui and I. ramphoceli were differentiated mainly by SB and SSB. While I. tiesangui has SB flattened and SSB rounded, I. ramphoceli has SB knob-like and prominent, and SSB large and homogenous. The shape of the sporocyst can also assist to identify because the sporocysts of I. tiesangui are more elongated when compared with I. ramphoceli (Table 3, Fig.2). The identification of these species depends on more careful and detailed observations of these features.

Isospora navarroi presented SB and SSB small and delicate, sometimes difficult to observe. Moreover, the ellipsoid shape of the sporocysts and the robust SRB of the sporozoites assist in identifying this species.

\section{CONCLUSIONS}

This study characterized sporulated oocysts of Isospora spp. morphologically and morphometrically.

The statistic evaluation revealed patterns and trends of coccidia, as well as those that are polymorphic.

Comparative studies revealed those coccidia identified by morphometry, in addition to confirm the description of new hosts. However, I. tiesangui, I. ramphoceli, I. navarroi and I. cadimi were identified safely by detailed under morphological study.

The essential feature of differentiation includes the SB and SSB bodies, which have been unique for each species.

Besides, D. cayana and T. palmarum were recorded as new hosts for I. sepetibensis and I. navarroi respectively.

Acknowledgements.- To the Brazilian Navy, especially to the commander of CADIM (Centro de Adestramento da Ilha da Marambaia), who enabled our access to Marambaia Island. We are also grateful for the use of some of the facilities of CADIM during the fieldwork.

\section{REFERENCES}

Araújo D.S.D. 2005. História Natural da Marambaia. Edur, Seropédica. 288p.

Berto B.P., Flausino W., Luz H.R., Ferreira I. \& Lopes C.W.G. 2008a. Three new Coccidian parasites of Brazilian Tanager (Ramphocelus bresilius dorsalis) from South America. Acta Protozool. 47:77-81.

Berto B.P., Flausino W., Luz H.R., Ferreira I. \& Lopes C.W.G. 2008b. Isospora cagasebi sp. nov. (Apicomplexa, Eimeriidae) from the bananaquit, Coereba flaveola of Brazil. Acta Parasitol. 53:117-119.

Berto B.P., Lopes B.B., Flausino W., Teixeira-Filho W.L. \& Lopes C.W.G. 2008c. Contribution on the study of Isospora hemidactyli Carini, 1936 and a report of an adeleid pseudoparasite of the house gecko Hemidactylus mabouia, from the Rio de Janeiro Metropolitan Region, Brazil. Revta Bras. Parasitol. Vet. 17:150-154.

Berto B.P., Flausino W., Almeida C.R.R. \& Lopes C.W.G. 2008d. Polymorphism of Tyzzeria parvula (Kotlán, 1933) Klimes, 1963 (Apicomplexa: Eimerii- 
dae) oocysts from the greylag geese Anser anser L., 1758 conditioned in two distinct sites. Revta Bras. Med. Vet., 30:215-219.

Berto B.P., Cardozo S.V., Teixeira-Filho W.L., Ferreira A.M.R. \& Lopes C.W.G. 2008e. Aflatoxin effect on the oocysts morphometry and contribution on the morphology of Eimeria bateri Bhatia, Pandey and Pande, 1965 of the Japanese quail Coturnix japonica, in Brazil. Revta Bras. Parasitol. Vet. 17:235-238.

Berto B.P., Flausino W., Luz H.R., Ferreira I. \& Lopes C.W.G. 2009a. Two new Isospora species from Brazilian tanager (Ramphocelus bresilius dorsalis) of South America. Parasitol. Res. 105:635-639.

Berto B.P., Luz H.R., Flausino W., Ferreira I. \& Lopes C.W.G. 2009b. New species of Eimeria Schneider, 1875 and Isospora Schneider, 1881 (Apicomplexa: Eimeriidae) from the short-crested flycatcher Myiarchus ferox (Gmelin) (Passeriformes: Tyrannidae) in South America. Syst. Parasitol. 74:75-80.

Berto B.P., Flausino W., Luz H.R., Ferreira I. \& Lopes C.W.G. 2009c. Isospora mionectesi sp. nov. (Apicomplexa, Eimeriidae) from the grey-hooded flycatcher, Mionectes rufiventris in Brazil. Acta Parasitol. 54:301-304.

Berto B. P., Luz H. R., Flausino W., Ferreira I. \& Lopes C.W.G. 2009d. Isospora piacobrai n. sp. (Apicomplexa: Eimeriidae) from the masked yellowthroat Geothlypis aequinoctialis (Gmelin) (Passeriformes: Parulidae) in South America. Syst. Parasitol. 75:225-230.

Berto B.P., Luz H.R., Ferreira I., Flausino W. \& Lopes C.W.G. 2010a. Two new hosts for Isospora tiesangui Berto, Flausino, Luz, Ferreira \& Lopes, 2008 (Apicomplexa: Eimeriidae). Revta Bras. Med. Vet. 32:168-171.

Berto B.P., Flausino W., Luz H.R., Ferreira I. \& Lopes C.W.G. 2010b. Isospora ramphoceli n. sp. from the Brazilian tanager (Ramphocelus bresilius dorsalis) in South America. Zootaxa 2650:57-62.

Berto B.P., Flausino W., Luz H.R., Ferreira I., \& Lopes C.W.G. 2011. Isospora coerebae n. sp. (Apicomplexa: Eimeriidae) from the bananaquit Coereba flaveola (Passeriformes: Coerebidae) in South America. Revta Bras. Parasitol. Vet. 20:22-26

CBRO 2010. Lista das aves do Brasil. Rio de Janeiro, Comitê Brasileiro de Registros Ornitológicos. 36p.

Catchpole J., Norton C.C. \& Joyner L.P. 1975. The occurrence of Eimeria weybridgensis and other species of coccidia in lambs in England and Wales. Brit. Vet. J. 131:392-401.

Duszynski D.W. 1971. Increase in size of Eimeria separata oocysts during patency. J. Parasitol. 57:948-952.
Duszynski D.W. \& Wilber P.G. 1997. A guideline for the preparation of species descriptions in the Eimeridae. J. Parasitol. 83:333-336.

Fayer R. 1980. Epidemiology of protozooan infection: The Coccidia. Vet. Parasitol. 6:75-103.

Gardner S.L. \& Duszynski D.W. 1990. Polymorphism of eimerian oocysts can be a problem in naturally infected hosts: an example from subterranean rodents in Bolivia. J. Parasitol. 76:805-811.

Gomez F.M., Navarrete I. \& Rodriguez R.L. 1982. Influencia de los factores ambientales sobre diferentes poblaciones de Isospora lacazei Labbé, 1983 (Protozoa: Apicomplexa). Revta Iber. Parasitol. 42:185-196.

Hassum I.C., Valladares G.S. \& Menezes R.C.A.A. 2007. Diferenciação das espécies de Eimeria parasitas de ovinos pelo uso da regressão linear e algoritmos morfológicos. Revta Bras. Parasitol. Vet. 16:97-104.

IUCN 2011. International Union for Conservation of Nature and Natural Resources. Disponible at: <http://www.iucnredlist.org> Acess at Jan. 20, 2011.

Joyner L.P. 1982. Host and Site specificity, p.35-62. In: Long P.L. (Ed.), The Biology of the Coccidia. University Park Press, Baltimore.

Norton C.C. \& Joyner L.P. 1981. Eimeria acervulina and E. mivati: oocysts, life-cycle and ability to develop in the chiken embryo. Parasitology 83:269279.

Parker B.B. \& Duszynski D.W. 1986. Polymorphism of eimerian oocysts: A dilemma posed by working with some naturally infected hosts. J. Parasitol. 72:602-604.

Pereira M.J.S., Fonseca A.H. \& Lopes C.W.G. 2001. Regressão linear na caracterização de variações morfométricas em Coccidia. Revta Bras. Parasitol. Vet. 10:75-78.

Ramirez L., Teixeira-Filho W.L., Berto B.P., Balthazar L.M.C. \& Lopes C.W.G. 2009a. Caracterização de variações morfométricas com a utilização da regressão linear em espécies do gênero Eimeria em caprinos da região serrana do estado do Rio de Janeiro, Brasil. Revta Bras. Med. Vet. 31:175180.

Ramirez L., Berto B.P., Teixeira-Filho W.L., Flausino W., Meireles G.S., Rodrigues J.S., Almeida C.R.R. \& Lopes C.W.G. 2009b. Eimeria bareillyi from the domestic water buffalo, Bubalus bubalis, in the State of Rio de Janeiro, Brazil. Revta Bras. Med. Vet. 31:261-264.

Sampaio I.B.M. 2002. Estatística aplicada à experimentação animal. FEPMVZ Editora, Belo Horizonte. 265p.

Sick H. 1997. Ornitologia Brasileira. Nova Fronteira, Rio de Janeiro. 862p. 